\title{
A New Talent Training Mode Based on the Coordinated Development of Project Driven and Business School
}

\author{
Qiong Wu \\ Wuhan Donghu University, Wuhan City, Hubei Province, 430212, China
}

Keywords: Project driven; Business school; Coordinated development; Talent training; Mode innovation

\begin{abstract}
School business cooperation and business school are the important measures that vocational schools seek their development and realize the integration with the market with vigorously improving the quality of education, targeted for business to train front-line practical and technical personnel of important initiatives. The purpose is to let students learn and practice in the business and let the school and business complementary to each other and share resources on the advantages of equipment and technology, so that to improve the pertinence and effectiveness of education, and improve the quality of skilled personnel. Based on the author's teaching and practical experience, this paper first analyzed the advantages of talent training methods of project driven and business school, and then discussed the key issues of talent training mode of project driven and business school.
\end{abstract}

\section{The Advantages of Talent Training Mode of Project Driven and Business School}

The advantage of talent training mode of the project driven. The project driven mode means that the school and the business cooperate with each other through specific projects to adjust the orientation and training target of relevant majors, and formulate and perfect the theoretical teaching system and practical teaching system. The concrete project is negotiated by the school and business and the project is the basis for cooperation between the two sides. Project driven mode is a kind of form to be completed by the cooperation process so that to realize the training work. Relying on the talent training mode of "project driven", we directly introduce the design, development, project or production task of the business into the classroom directly. Teachers carry out teaching activities guided by the "project", and students learn by completing the project. We also emphasize that theoretical knowledge revolving around skills training so that each subject can be taught, demonstrated, and trained simultaneously. Students learn to do and learn by doing; teachers teach students according to their aptitude. Moreover, teachers encourage students who have strong knowledge receptivity to learn by themselves, and help students who do not have strong knowledge receptivity to consolidate the knowledge; in addition, teachers give individual guidance to students with poor knowledge receptivity so as to master relevant knowledge.

The advantages of talent training mode of business school. Animation design and production specialty of art and design major also develop ideas on the school running mode of school business cooperation. Through exploration and practice, we can effectively utilize the advantages of the business resources and the technological and human advantages of the college, and guide the business to enter the Institute of information technology and art. The business provides design and project resources, and the college provides venues. The college will appoint teachers with 
professional abilities to form a mentor studio, and take project benefit sharing and risk sharing to carry out project cooperation. The instructor of the studio is a teacher, who is a student of all grades in the school. The business sends some technical personnel to assist the project and part-time teacher as a tutor studio. The tutor studio adopts the business operation mode completely with entering 10 students or so, and gives certain salary according to the project, and implements the strict import and export system. The students in the supervisor studio will implement the principle of credit interchange. The students will complete the project and the tutor's opinion as the basis of the credit exchange, and submit the project results to the teacher for the job in exchange for credits.

\section{The Key Problems in the Talent Training Mode of Project Driven and Business School}

Comprehensively considering the educational, social and economic benefits. "Project driven and school business" is the training base that introduce production equipment and production technology of business to the school, and it can make the school more effective in teaching, learning and doing together. Therefore, students can contact the business culture in the usual campus learning. The management of the business has fostered the consciousness of "business employees", the consciousness of "zero deficiency", the sense of unity and cooperation and the initiative of work. In return, the trained and qualified products belong to the business, and students may be directed to the business after graduation. In a specific period of time, students can get certain labor remuneration. Practice has proved that "project driven and business school" has significant educational, social and economic benefits. For example, it solves the problems of students' study and life in family difficulties, the problems of teaching practice equipment in schools, and solves the problems of human resources and cost of business.

Schools need to consider a variety of factors in order to introduce productive business: The first is to closely integrate regional economic and industrial structure, relying on the existing professional resources of the school, which will confirm to the professional long-term development plan; the second is that we should not have an insatiable desire for the business. Usually, in one of these workshops, the workshop has relative independence; the third is that required technical content should be moderate. If technical content is too high, students are not easy to use it with low efficiency and high reject rate in production practice. As a result, schools and businesses are unable to afford high costs. If the technical content is too low, students will master quickly. Moreover, simple, repetitive and mechanical training for students to improve the skills of students are of little significance, and tired heart will also increase the rejection rate; fourth is that the business must be pollution-free with no noise; fifth is the products must have the market, and the product cycle must be in growth or maturity, which also need to consider the possibility of upgrading and sustainable development; without any benefit return, the business can not cooperate with the school for a long time; the sixth is to consider the transportation cost and management cost, and the the business should not seek far and neglect what lies close at hand. The seventh is that the school can also play the professional advantages, encourage and support professional teachers founded or the lead business.

The school invites business or business to come to the school, and the two sides value each other's resources. The school has resources of human and plant, and business is equipped with market-oriented products, technology, capital and equipment, etc. The cooperation between the two sides is based on the principle of sharing resources and mutual benefit. According to the different situation, the mode of cooperation is not a set. We have all kinds of types, including contracted management, independent management, cooperative production and processing.

Distinguish rights and responsibilities, and establish mechanisms to ensure the normal 
operation of the base. In accordance with the principle of equality, voluntariness and mutual benefit, schools and business negotiated and established the business school cooperation mechanism. The school agrees that the business will be engaged in production activities on the campus training base and provide necessary support for its production. The business provides service for the schools to carry out teaching and research activities according to the agreement reached by both parties. Therefore, we should make clear their respective rights and obligations, and establish a suitable management system to ensure the normal development of production and teaching activities. First of all, it is necessary to formulate management organization forms, fixed assets investment and management, practical teaching organization, daily attendance management and technical management, "double teacher" quality teacher training, staff training, technology research and development, internship and internship environment, student living allowance and operation standard training and other management systems. The school agreed with the business. First, students must strictly abide by the rules and regulations of the business and work procedures in the internship period. If the students violate discipline badly, business has the right to terminate the student internship and informs the school. During the internship, when the accident occurred in accordance with the normal operation procedures for students, the responsibility was borne by business. The expenses involved in student safety accidents shall be settled in accordance with the relevant provisions, and all expenses arising from the safety accidents of the equipment shall be borne by the business; school should take the responsibility if students do not comply with the safety rules for safe operation in the internship. The expenses involved in student safety accidents shall be settled in accordance with the relevant provisions. Third, according to the term professional teaching plan, an internship program is set up, including internship time, content, number of people, and the school should provide the information to business a week ahead of schedule, and the business is responsible for arranging and organizing the internship. Fourth, the two sides clearly defined cooperative ownership of equipment, and the ownership of the equipment belongs to the purchaser. The equipment should be inventoried, and all equipment should be shared. The daily maintenance of the equipment are in the charge of the business. The expenses are borne by the business. During the term of validity of the agreement, the business shall not phase out equipment because of the aging of the equipment or the use of the equipment. In the process of organizational practice (including skills identification, skills competition, social services), business need materials, and fees should be charged by the school. According to the content of the internship, the school can make plans and purchases supplies, and also business can be commissioned to buy. As a result of equipment problems affecting practice, full responsibility be took by business; as a result of practice materials affecting the practice, full responsibility be took by the school. In any case, the factory ownership belongs to the school. Without the approval of the school and the design department and specially designed, it can not be changed. Business needs to operate lawfully and assumes sole responsibility for profits and losses, and the school does not bear any legal responsibility in the economy.

In addition, the two sides should set up a teaching coordination group, comprehensive coordination and organization, and carry out teaching activities. Moreover, both sides should solve the problems arising from teaching, evaluate the quality of teaching and coordinate and improve teaching activities.

Personnel sharing and post interaction create teacher team of "Double qualified teacher". "Double qualified teacher" is the precious wealth of vocational school, and it is the basic guarantee to promote the connotation of school and improve the quality of education. It is the most critical factor in the quality of vocational education. To be sure, on the one hand, many schools are eager to 
send their teachers to the post office, so that they can improve their professional skills and level of operation, and understand the new technology, new equipment and new technology. Further, they hope that teachers can understand the requirements of the professional skills of the operation level, master the process and operation standards, and actively participate in enterprise staff training and product development and strive to improve the skills level of operation; on the other hand, the school also eager to recruit highly skilled personnel to school and make part-time teaching jobs. However, as a result of various factors, there is still exists the situation of "gilded without doors, worship is not easy". When the school introduced business into campus, the two families became one for mutual benefit between teachers and technicians of the business, so that to create the conditions for the interaction. The school should combine teachers' professional characteristics and make reasonable allocation and overall arrangement, so that to let them participate in the production and realize the implementation of job type business practice training. As a result, it will make them equip with the dual identity of teacher and employee. In the personnel arrangement, we should pay attention to the realization of multi-professional and multi-level requirements. For example, when introduce the machinery business, it is tantamount to waste job resources if only part of school teachers to arrange mechanical production line. In order to make full use of resources, the school can arrange the accounting professional teachers to play for accounting, marketing professional teachers as sales; the school arranges the computer specialized teacher takes responsibility for each kind of management system establishment and the maintenance, and arranges the mechanical teacher to participate in the production process development and the quality examination. Only in this way can the teachers of the school be more integrated into the training of business, and also enrich their own skills. The technical personnel of business has its advantages with rich industry experience. In order to improve their production efficiency, they will unreservedly to teach students skills when students participate in business production training. This virtually bears the teaching task of school professional skills teachers, and is a powerful complement to school professional teachers.

\section{Summary}

Coordinated development of project driven and business school is a new talent training mode, which cultivates talents in a better way. However, to ensure continuous and stable operation of the training base, the key is to establish school business win-win mechanism. In order to realize the complementary advantages of both sides and mutual benefit, we must find the link of cooperation between the two sides and entry points, so that to form an effective benefit sharing mechanism. In addition, after introducing the "business school", the nature of the business for profit has not changed, and there is a certain contradiction between the training of teaching and the completion of production tasks. Therefore, the form of teaching organization should be flexible and meet the requirements of business. At the same time, we should actively promote the teaching modes of task driven, process oriented and project-based teaching model. We should boldly reform the teaching content and teaching methods so as to meet the requirements of productive training.

\section{Acknowledgements}

Hubei Province education science project(2015) - Research on Innovation of Training Mode of Applied Technical Talents about Coordinated Development of Project Driven and Business School.

Hubei Province planning issues of Education Science in 12th Five-Year(2015) : A New Talent Training Mode Based on the Coordinated Development of Project Driven and Business School(item 
number: 2015GB196).

\section{References}

[1] Zhang Liming. Research and Practice on the Operation Mode of Business School Co-build Second Level Colleges and Universities[J]. Journal of Shenzhen Polytechnic, 2015, (01): 65-69.

[2] Yang Congya. Exploration and Practice of "Business School" Teaching Mode[J]. Chinese Vocational and Technical Education, 2014 (14): 29-32.

[3] Wang Yunjiang, Deng Zhenyi, Bai Cunyou. The Resource Sharing Mechanism of Business School Innovative Cooperation between School and Business[J]. China Vocational and Technical Education, 2014, (04): 57-60.

[4] Zhu Youming. Analysis of the Problems of Vocational Education of Business School[J]. Petroleum Education, 2013, (04): 97-101.

[5] Ni Xiangming, Cao Mingshun, Zhao Fen. Exploration and Practice of Cooperation of Business School Mode[J]. Journal of Xiangfan Vocational and Technical College, 2012, (01): 30-31+38.

[6], Jiang Yong. Problems and Solutions Encountered in Business School[J]. Dazhong Science and Technology, 2010, (05): 208+200.

[7] Ma Guang, Wang Zhiming. Practice of Building Productive Training Base of Business School[J]. Vocational and Technical Education, 2008, (32): 60-61. 